\title{
Legitimate Diversity: The New Challenge of European Integration
}

by Fritz W. Scharpf

\section{Article by an MPIfG researcher}

Fritz W. Scharpf: Legitimate Diversity: The New Challenge of European Integration.

In: Zeitschrift für Staats- und Europawissenschaften 1(1), 32-60 (2003). Nomos

The original publication is available at the publisher's web site: http://dx.doi.org/10.1515/zfse.1.1.32

Present debates on a European constitution should consider not only the legitimacy, but also the problem-solving effectiveness of EU decision making. The existing governing modes (supranational centralization, joint-decision making, intergovernmental agreement) are not capable of dealing with the three main challenges the European Union is currently confronted with: an improved Common Foreign and Security Policy, enlargement towards the East and safeguarding the plurality of European welfare states. Neither resorting to the principle of "subsidiarity" nor consequent majority voting would provide real solutions. Effective European decisions respecting legitimate national diversity could rather be enhanced by improving the procedures of "Enhanced Cooperation" and the "Open Method of Coordination".

Die gegenwärtige Debatte über eine europäische Verfassung sollte sich nicht nur mit der Legitimität von EU-Entscheidungen, sondern auch mit deren Problemlösungsfähigkeit befassen. Die Leistungsfähigkeit bisheriger Verfahren (hierarchische Steuerung, Gemeinschaftsmethode, intergouvernementale Zusammenarbeit) scheint begrenzt angesichts jener großen Herausforderungen, vor denen die Europäische Union gegenwärtig steht: die Effektivierung der Gemeinsamen Außen- und Sicherheitspolitik, der Vollzug der Osterweiterung sowie der Erhalt der nationalstaatlichen Wohlfahrtsregime. Weder eine konsequente Anwendung des Subsidiaritätsprinzips noch der Übergang zu Mehrheitsentscheidungen bieten sich als brauchbare Reformoptionen an. Eher können gleichermaßen effektive und legitime Entscheidungen im Rahmen der Europäischen Union durch eine Verbesserung der „Verstärkten Zusammenarbeit" wie der „Methode der offenen Koordinierung“ erzeugt werden. ${ }^{1}$

\section{The Challenge of Present Constitutional Debates}

In contrast to earlier periods of institutional reform, the present debate over a European Constitution, fueled by frustration over the meager outcomes of the Nice Summit, appears to be at the same time more systematic and less connected to substantive policy problems or goals. Whereas the Single European Act had

1 Written during a period of research and teaching which, at the invitation of Professor Renaud Dehousse, I enjoyed at the Centre Européen des SciencesPo, Paris. 
introduced limited institutional reforms that were considered essential for reaching the goals of the Internal-Market program, and whereas Maastricht was about the specific institutional requirements of a common currency, the present Convention and discussions accompanying its work seem to be mainly concerned with competing visions of the Union's finalite and its ultimate institutional architecture. Compared to the piecemeal institutional engineering, or even tinkering, that characterized the work of earlier Intergovernmental Conferences (IGCs), the more general discussions of Europe's future shape have the advantage of being more easily communicated and understood in public discourses, and of generating wider media attention.

At the same time, however, proposals for institutional reform that are not plausibly linked to agreed-upon substantive goals or urgent policy problems are less likely to gain support among political actors who are not already committed to European political unification for its own sake, let alone among "Euroskeptics" whose agreement will still be necessary in subsequent IGCs and Treaty ratification procedures. Moreover, since the constitutional debates seem primarily concerned with a perceived "European democratic deficit" (which tends to be defined by reference to parliamentary practices at the national level) while the Convention is dominated by national and European members of parliament, the proposals that will emerge from these discourses are more likely to improve the institutional position of the European Parliament than to address the increasing "performance deficits" of the European Union. If that should happen, and if such proposals should in fact be adopted, the Union may find itself confronted with rising democratic expectations and subsequently, as its performance is unlikely to improve, with even deeper disappointment and a wider legitimacy gap than before.

If this outcome is to be avoided, proposals for institutional reform should be evaluated not only from the perspective of "input-oriented" democratic legitimacy (whose glib equation with the institutional self-interest of the European Parliament needs to be challenged in any case) but also from the "output-oriented" perspective of problem-solving effectiveness. Since present European institutions have allowed and legitimated the creation of the Single Market and Monetary Union, proposals for change ought to be justified as being necessary for dealing with manifest new policy challenges which cannot be met within the present institutional framework. The most important among these seem to be

- the challenges of a Common Foreign and Security Policy that have become manifest in the Balkans and after 11 September 2001;

- the challenges arising from Eastern enlargement; and

- the challenges to the viability of national welfare states that arise from the successful completion of the Internal Market and the Monetary Union. 
In order to appreciate the institutional implications of these challenges, however, it is also necessary to understand the functioning of present EU institutions and the limits of their problem-solving capacity. I will begin, therefore, with a brief overview of the principal "modes" of EU policy making - defined by participation rights and decision rules - for which I will use the labels of "intergovernmental negotiations", "joint-decision making" and "supranational centralization" ${ }^{2}$ and I will then proceed to discuss the new policy challenges with regard to the strengths and limitations of these present modes of policy making.

\section{The Plurality of European Governing Modes}

Like the political systems of nation states ${ }^{3}$, the European Union resorts to differing governing modes in different policy areas. Nevertheless, since European governing institutions are being created by the member states, the initial mode in all policy areas must be intergovernmental agreement. It is the governments of member states who must decide that certain policy choices, which otherwise would be exercised autonomously at national or subnational levels, should be transferred to the European level. In the same process, moreover, governments must also decide on the institutional mode in which these European policy choices should be reached. They may maximize their own roles by choosing the mode of "intergovernmental agreement"; they may move matters into the "jointdecision" mode involving the Commission, the Council and the European Parliament; or they may directly empower the Commission, the European Court of Justice or the European Central Bank to adopt policy choices in the "supranational-centralized" mode. ${ }^{4}$ These modes differ in their capacity to achieve

2 Scharpf, F. W.: Notes Toward a Theory of Multilevel Governing in Europe, in: Scandinavian Political Studies 24/1 (2001), 1-26.

3 In Germany, for instance, the characteristic governing mode for many policy areas is a form of jointdecision system involving the federal government and its parliamentary majority in negotiations with the Länder; in other policy areas, however, the Länder have no policy making role and the government is instead involved in "neo-corporatist" negotiations with peak associations; in still other policy areas, the mode of governing is straightforwardly majoritarian; and given the large roles of the Constitutional Court and of the Bundesbank, important policy choices are also made in a centralized mode.

4 A (rational-choice) theory explaining these choices of governing modes would have to simultaneously consider the pressure of problems that could not be resolved by purely national action and the anticipated problems that national governments would have to cope with if European policy choices should violate important national interests or politically salient constituency preferences. These anticipated problems could be represented by three basic game constellations - the Prisoner's Dilemma (justifying resort to supranational solutions), the Battle of the Sexes (suggesting the joint-decision mode), and constellations where common interests are dominated by conflict over the choice of a solution (where governments are 
effective policy choices in the face of conflicts of interest among member states, and by empowering different actors, they will affect the policy outcomes that are likely to be achieved. ${ }^{5}$ They also differ with regard to the range of choices that could be legitimately taken. ${ }^{6}$

\section{Supranational Centralization}

In the supranational-centralized mode, policy choices are taken by the Commission, the European Court of Justice or the European Central Bank without depending on the agreement of individual member governments, of the Council or of the European Parliament. To the extent that these European-level institutions can be considered as single (corporate) actors with a capacity for strategic action, this mode has the characteristics of "hierarchical direction" 7 or of a (constitutional) "dictatorship". In the European polity, the establishment of this mode is a two-step or three-step process. At bottom, there must be an intergovernmental agreement on the Europeanization of the policy area. This agreement may also formulate a basic policy choice and then delegate its further specification and enforcement to a supranational institution which is allowed to exercise its discretion without the further participation of national governments. The clearest example of a two-step establishment of the supranational-centralized mode is provided by the authority of the European Central Bank over Euro-

most likely to insist on the mode of intergovernmental agreement). But of course, path-dependent institutional evolution and the strategies of corporate actors created by intergovernmental agreement, may cause subsequent departures from the original "equilibrium" solution.

5 Héritier, A.: Market Integration and Social Cohesion, in: Journal of European Public Policy 8/5 (2001), 825-852. Even though Adrienne Héritier explicitly refers only to decision rules, her distinction between "Treaty revision", "internal market" and "competition paths" is parallel to the three modes of policy making discussed here. Focusing on the field of utilities regulation, she shows how the choice among the three paths affects the relative weight given to market-liberalizing and social-cohesion concerns in European regulations of public services.

6 Héritier (op. cit.) also shows that specific policy initiatives may be plausibly introduced within one or another of these governing modes - which implies that the choice of mode may itself become the object of a strategic game.

7 Scharpf, F. W.: Games Real Actors Play, Boulder, 1997, chapters 3 and 8.

8 Holzinger, K.: Transnational Common Goods, Habilitation thesis, Universität Bamberg, 2002. In Holzinger's use, the term retains its pejorative implications which, in my view, prevent a full and fair exploration of the problem-solving potential of the hierarchical mode and of institutional arrangements that could ensure the "benevolent" use of dictatorial powers. On the other hand, the unqualified enthusiasm with which "independent" constitutional courts and central banks are celebrated in much of the legal and economic literature appears to be equally blind to the policy risks of dictatorship and its costs in terms of democratic legitimacy. 
pean monetary policy. Its mandate to "maintain price stability" (Art. 105 TEC) was defined through Treaty negotiations, and in carrying out this mandate the Bank is more insulated against the influence of EMU member governments than is or was true of any national central bank, including the German Bundesbank.

The same two-step structure is in place in all other policy areas where the Treaties include directly applicable prohibitions and obligations addressed to member states or corresponding rights of individuals and firms. In this case, the power of the Commission to initiate treaty infringement proceedings against individual member states and the power of the European Court of Justice (ECJ) to issue formally binding and enforceable interpretations of these Treaty obligations could only be reversed through unanimously adopted and ratified amendments of the text of the Treaties. In practice, therefore, the power of Treaty interpretation has created a capacity for supranational-centralized policy making in all areas where Treaty provisions are directly applicable.

With few exceptions (one of which is the injunction against gender discrimination in employment relations), these conditions apply in policy areas promoting economic integration and market liberalization. Here, once the basic commitment was agreed-upon, the interest constellation could be construed as a symmetrical Prisoner's Dilemma: All member states would be better off if the commitment were carried out in good faith, but all would also be exposed to the freeriding temptations of protectionist practices. If that was anticipated, delegating the power of enforcement to supranational actors, the Commission and the Court, would indeed be justified as serving the enlightened self-interest of all member states. ${ }^{9}$ If this conceptual frame was accepted, one could still expect that individual decisions would conflict with the short-term interests of national governments ${ }^{10}$ - but their opposition would undermine neither the explanation nor the legitimacy of the delegation of regulatory powers to supranational authorities. It also implied, however, that the politically uncontrolled evolution of European competition law could lead to extensive interpretations of Treaty commitments that might, and often did, go beyond the original intent of the treaty-making governments. ${ }^{11}$

To a lesser extent, supranational policy-making powers also arise from a threestep process - where intergovernmental agreement on the Treaties has created a European competence, but left the definition of substantive policy choices to directives and regulations adopted in joint-decision processes involving the

9 Moravcsik, A.: The Choice for Europe, Ithaca, 1998.

10 Burley, A.-M./Mattli, W.: Europe Before the Court: Political Theory of Legal Integration, in: International Organization 47/1 (1993), 41-76.

11 Scharpf, F. W.: Governing in Europe, Oxford, 1999. 
Commission, the Council and, increasingly, the Parliament. In the enforcement of these more specific rules of "secondary" European law, opportunities for discretionary interpretation by the Commission and the Court are more narrowly circumscribed, but since such interpretations could only be politically corrected upon a legislative initiative from the Commission and with the agreement of at least a qualified majority of Council votes, the capacity for supranationalcentralized policy making deviating from the preferences of the Council and the Parliament exists here as well.

These centralized powers of interpretation and enforcement exercised by the Commission and the Court did account for the progress of economic integration in the periods of political stagnation in the 1970s and early 1980s, and they also account for the rapid advancement and radicalization of market-liberalizing policies once the basic political commitments had been agreed upon in the Single European Act of 1986. Moreover, these powers could also be employed strategically by the Commission to induce reluctant governments to agree on additional legislation that would again advance economic liberalization. ${ }^{12}$ It is true that some governments have repeatedly tried to promote Treaty revisions or protocols protecting existing public services and infrastructure functions against the impact of European competition law. As of now, however, these efforts have not succeeded in imposing legally effective limitations on market liberalization, and it remains to be seen if such proposals will fare better in the present Convention.

\section{Joint-Decision Making}

The normal mode of policy-making in the "first pillar" of the European Community (which the Commission describes as "the Community Method") has the characteristics of joint-decision making involving supranational actors as well as national governments. It takes the form either of "directives" that need to be transposed into national law by the legislative processes of member states, or of "regulations" that take direct effect. Both need to be adopted, on the initiative of the Commission, by the Council of Ministers acting increasingly under rules of qualified-majority voting (QMV), and by the European Parliament (EP) whose role was strengthened through the increasing use of co-decision procedures. ${ }^{13} \mathrm{In}$

12 Schmidt, S. K.: Commission Activism. Subsuming Telecommunications and Electricity under European Competition Law, in: Journal of European Public Policy 5/1 (1998), 169-184.

13 Héritier (op. cit.) has shown how the empowerment of the EP has strengthened social-cohesion concerns in the regulation of liberalized public utilities. 
preparing its initiatives, the Commission consults (generally at its own discretion) a wide range of interest associations, firms, non-governmental organizations and expert committees. Similarly in preparing its common position, the Council relies on the Committee of Permanent Representatives (COREPER) and the preparatory work of specialized committees representing the governments of member states. As the role of the European Parliament has been strengthened, specialized EP committees and negotiations between these and Council committees have also increased in importance. Moreover, if directives need to be "implemented" through more detailed regulations, this is generally delegated to the Commission, acting in "Comitology" procedures involving, again, civil servants and experts nominated by member governments. ${ }^{14}$

Taken together, these institutional arrangements provide so many veto positions, and so many access points for interest groups, that the actual policies produced by joint-decision processes are unlikely to violate status-quo interests that have high political salience in member states or that are represented by wellorganized interest groups. At the same time, however, the central role of the Commission, and the commitment of "Europeanized" national representatives in COREPER and in Comitology committees generally ensure that conflicting initial positions are not taken at face value, and that opportunities for creative "winwin" solutions or mutually acceptable compromises are actively explored. As a consequence, agreement is reached more frequently than one would expect on the basis of a static analysis of postulated national interests, and it may also be assumed that these outcomes are generally legitimated by a broad consensus among the parties involved. ${ }^{15}$

By the same token, however, the multi-actor negotiations required here tend to be not only complex but quite intransparent - which is easily criticized as violating norms of democratic accountability. A more relevant line of criticism points out that the joint-decision mode, like all multiple-veto systems ${ }^{16}$, has a systematic bias favoring status-quo interests over political preferences that could only be satisfied by substantial changes of the status quo. ${ }^{17}$ Moreover, consensusseeking processes are slow, and if they are successful the resulting legislation is likely to be either at the lowest common denominator or encumbered by

14 Joerges, C./Vos, E. (eds.): EU Committees: Social Regulation, Law and Politics, Oxford, 1999.

15 Eichener, V.: Das Entscheidungssystem der Europäischen Union, Opladen, 2000.

16 Tsebelis, G.: Decision Making in Political Systems, in: British Journal of Political Science 25/3 (1995), 289-326.

17 Scharpf, F. W: The Joint-Decision Trap: Lessons from German Federalism and European Integration, in: Public Administration 66/3 (1988), 239-278. 
excessive detail. ${ }^{18}$ In other words, the problem-solving effectiveness of the jointdecision mode is limited in policy areas where conflicts of interest have high political salience in the constituencies of member governments, and in general the efficiency of policies that can be adopted under these constraints leaves much to be desired.

\section{Intergovernmental Agreement}

The mode of intergovernmental agreement is not limited to the foundational functions of allowing the Europeanization of public policy in areas that were hitherto under autonomous national control - either through explicit Treaty revisions or through unanimous agreement in the Council under the "necessaryand-proper" clause of Art. 308 (ex 235) TEC. It also applies in policy areas where governments have recognized a need for European action but where, in the view of at least some of them, the likelihood or the potential (economic or political) costs of decisions going against their own preferences is thought to be so high that they cannot accept QMV in the Council. Thus, the unanimity rule has so far been maintained in the fields of tax harmonization, budget decisions, and a range of social-policy areas. If reservations are even stronger, governments will also want to avoid being put on the spot by the Commission's monopoly of legislative initiatives or having to negotiate over compromises with the European Parliament, and they will seek to disable the supranational interpretative and enforcement powers of the Commission and the Court. These have been the conditions characterizing intergovernmental policy making in the second and third "pillars" of the Treaty of European Union dealing with "Common Foreign and Security Policy" and "Justice and Home Affairs", even though some of the latter competencies on visas, asylums and immigration are in the process of coming under first-pillar rules (Arts. 61-69 TEC). In recent years, finally, the European Council has increasingly come to circumvent the Commission's monopoly of legislative initiatives by defining items on the European policy agenda in its Summit meetings which then have to be worked out through legislation or ad-hoc intergovernmental arrangements.

In all these instances, individual national governments have a veto - which they may employ in the "bloody-minded" defense of narrowly-defined and short-term

Both possibilities are entirely plausible in multi-veto systems: Low-regulation countries having no interest in common European solutions may veto all rules providing higher levels of protection. By contrast, high-regulation countries with an interest in a common solution may still use the veto threat to ensure that their own particular set of rules is included in it. 
national (political or economic) self-interest or with a view to either common European interests or to the longer-term benefits expected from closer cooperation and policy coordination. In any case, however, the outcomes of negotiations in the intergovernmental mode tend to have higher political visibility than is generally true of European policies adopted in the supranational or joint-decision modes - which also means that they are more likely to be scrutinized by national opposition parties and the media, and that governments must generally be able and willing to publicly defend their support in terms of the (enlightened) selfinterest of national constituencies. As a consequence, intergovernmental agreements are supported by the legitimacy of the governments that conclude them, but their problem-solving effectiveness is more narrowly restricted to solutions that do not violate the intense preferences of national constituencies.

\section{New Policy Challenges}

Present European institutions, it is fair to say, have allowed member states to achieve a degree of market integration, economic interaction and transnational mobility that has gone far beyond the original aspirations of the governments that had concluded the Treaty of Rome. In doing so, they have also contributed to the unprecedented period of peace that Western Europe has enjoyed over the last half-century. As European integration has succeeded in removing economic boundaries among member states, it has also reduced the political salience of national boundaries to such a degree that territorial disputes have become a nonissue and war among member states has become unthinkable. In achieving these outcomes, European integration has relied on modes of governing which, though not always very efficient, have been adequate to their specific tasks, and whose legitimacy, though not "democratic" in the sense prevailing in constitutional democracies at the national level, is supported by normative arguments that are sufficiently persuasive for the functions that are in fact performed.

It should also have become clear, however, that both the effectiveness and the legitimacy of these governing modes are limited, and that one could not and should not expect that in their present shape they could cope with an unspecified range of new challenges. Thus, if the present constitutional debate is to be pragmatically meaningful, it ought to focus on these limitations - and thus on the question whether the foreseeable challenges to the Union and its member states could or could not be met within the present institutional framework of the Union. 


\section{Common Security Capabilities (CFSP and ESDP)}

The most serious challenge is also the one about whose possible resolution I know the least. ${ }^{19}$ In the postwar decades, the twin problems of European security - "keeping the Russians out and the Germans down" - were resolved by the NATO alliance under the hegemonic leadership of the United States. With the end of the Cold War, the Soviet threat evaporated while the German threat, if it existed, had dissolved in the process of European integration. However, as Communist rule disintegrated, suppressed ethnic and religious conflicts re-emerged not only in the successor states of the Soviet Union but also closer to the EU, in the former Yugoslavia and its Balkan neighbors - and while they did not constitute an immediate military threat to Western Europe, it was clear that EU member states would be morally and practically affected by escalating violence and genocide in their own "back yard", by waves of refugees, and by conflicts among their immigrant populations. There was no question that maintaining or re-establishing peace and order in the Balkans was in the immediate and urgent self-interest of EU member states.

While NATO eventually did get involved in Bosnia and the Kosovo, it also became clear that America had turned into a reluctant hegemon in areas of the world where its own security and economic interests are not directly at stake. At the same time, however, the Balkan interventions revealed that European countries, in spite of long-standing attempts to coordinate their foreign policies, were still working at cross purposes and could not agree on common strategies that would have allowed them to intervene jointly at a time when this could still have staved off the escalation of conflict. Even more important was the recognition that, individually and jointly, they lacked the reconnaissance and logistic capabilities as well as the trained intervention forces and the specialized weaponry that would allow them to engage on their own in peace-making missions if the United States were not willing to assume the leading role and to carry the major burden of actual operations. ${ }^{20}$

In the meantime, EU governments have strengthened the intergovernmental institutions for coordinating their Common Foreign and Security Policy ${ }^{21}$ and they have at last responded to Henry Kissinger's request of a European phone number by appointing Javier Solana as their High Representative (HR-CFSP). In

19 Much of what I know about the field is owed to the work of, and discussions with Jolyon M. Howorth who, however, is in no way responsible for my use or misuse of this knowledge.

21 Hoffmann, S.: Towards a Common European Foreign and Security Policy?, in: Journal of Common Market Studies 38/2 (2000), 189-198. 
addition, they are in the process of building common military capabilities that would allow either autonomous action or more co-equal cooperation with the United States. Thus, at Helsinki they agreed to create the institutional infrastructure of a European Security and Defense Policy (ESDP) which also includes the commitment of all EU member states (with an opt-out for Denmark) to contribute national contingents to a European Rapid Reaction Force (ERRF). In the process, governments also seemed to have achieved a remarkable convergence of cognitive and normative orientations - apparently assisted through intense and frequent "transgovernmental" interactions of the military and foreign-policy staffs and elites of the participating governments. ${ }^{22}$

Nevertheless, as the aftermath of 11 September and the war in Afghanistan has shown, the United States continues to act by its own insights; the military and diplomatic responses of its European allies are still determined nationally and in bilateral coordination with the U.S. government; and common European forces are not yet a factor that matters internationally. Moreover, the creation of ERRF has been delayed by financial squeezes and by the difficulties of combining the diverse offers of national contributions into an effective military capability. At the same time, political agreement on common strategies is impeded by the extremely high salience of military commitments in national politics - particularly in countries with a neutralist tradition or with significant segments of public opinion or governing parties committed to pacifism. In any case, however, the deployment of national contingents in military action is so closely associated with core notions of national sovereignty and democratic accountability that all attempts at coordinated action are likely to remain contingent on the outcome of time-consuming national deliberations.

In short, while coordination has been improved, CFSP and ESDP are still stuck in the intergovernmental mode which, in the absence of vigorous (and accepted) American leadership, will continue to prevent those rapid European responses which, in the crises of the past decade, might have averted the escalation of conflict and the later need for more massive interventions. At the same time, however, given the diversity of the international and military positions of its members, it seems unlikely that the EU as a whole could move CFSP/ESDP into the joint-decision mode, where national decisions might be replaced by Commission initiatives and qualified-majority votes in a (still to be created) Council of Defense Ministers. Under these conditions, needless to say, an effectively supra-

22 Howorth, J.: European Integration and Defence: The Ultimate Challenge?, Chaillot Paper No. 43, Paris, 2000; idem: European Defence and the Changing Politics of the European Union, in: Journal of Common Market Studies 39/4 (2001), 765-790. 
national-centralized solution, which would eliminate the control of national governments and national parliaments over the deployment of national contingents in common European missions, seems completely beyond reach.

\section{Eastern Enlargement}

The prospect of moving from the present fifteen to perhaps twenty-seven EU member states during the present decade is confronting the European polity with severe challenges. The most obvious problems of voting rules in the Council and of the size of the Commission were addressed at the Nice Summit in a not very convincing fashion. In fact, it has been shown that, compared to present QMV rules, the Nice Treaty will even increase the threshold of reaching majority decisions in the enlarged Council. ${ }^{23}$ However, what matters more in this regard is the dramatic increase in the economic, social, political-cultural and political-institutional heterogeneity among EU member states that Eastern enlargement will bring about. This will obviously affect the capacity of the EU to adopt new policies in the intergovernmental and joint-decision modes - a problem to which I will return in the next section. But it will also affect existing policies.

As I pointed out above, the application and enforcement of existing EU law is carried out, in the supranational-centralized mode, by the Commission and the European Court of Justice (and by the courts of member states when they follow the preliminary rulings of the ECJ in ordinary legal proceedings). Even though the power to interpret the law will often shade over into policy making, the Commission and the Court will normally remain within the frame of understandings that were shared among the governments that participated in the adoption of European rules - which also suggests that EU law and its interpretation will by and large reflect the generalized interests of the countries that were members at the time of its adoption. Since the massive expansion of the acquis communautaire through the Single European Act did occur only after Southern enlargement, and since the later accessions of Austria, Finland and Sweden involved countries that were, by and large, similar to the original member states, the enforcement of the acquis has so far not been considered particularly problematic. But that is changing with the accession of Central and Eastern European countries - whose governments had no voice in the accumulation of the existing body of European law, and whose economic, social and institutional conditions 
and interests differ fundamentally from those of the countries that had shaped its content over more than four decades. ${ }^{24}$

The potential problems are illustrated by the experience of German unification, when the West German currency and the complete acquis of West German law and governing practices were imposed in one full sweep - with the consequence that East German industries were more or less wiped out by international competition and that mass unemployment, social disintegration and political alienation still persist in Eastern Germany in spite of financial transfers amounting to five or six percent of West German GDP annually. ${ }^{25}$ It is of course true that Central and East European accession countries need not adopt the Euro immediately, and that, by the time of their entry into the EU, they will have had a longer period of capitalist and democratic transformation than was true of the GDR. But it is also true that the financial assistance they are likely to receive will not amount to anything like the West-East transfers in Germany. In any case, however, while the full application of some requirements may be postponed for limited transition periods, there is no question that the complete and uniform acquis will have to be accepted before accession is allowed, and that it will then be enforced through the usual supranational-centralized procedures.

The consequences could be destabilizing in one of two ways. The most likely outcome - under the counter pressures of political commitments to early enlargement and the formal rigidity of the Commission's negotiating stance - would be accession agreements containing unfeasible commitments to the uniform acquis, adopted with the tacit complicity of Commission representatives in the expectation that lax implementation will be tolerated. But since the gap between what is legally required and what is economically affordable and politically feasible will be so wide, implementation deficits could not go unnoticed. In the accession countries, the cynicism toward EU law would infect the nascent respect for the rule of law in general; and as firms and interest groups in present EU member states become aware of illegal competitive advantages that accession countries are gaining through the lax enforcement of EU rules, compliance may be undermined in EU-15 countries as well.

In the less likely scenario, the Commission would not tolerate lax implementation and would use its considerable sanctioning powers to force governments in

24 Müller, K.: The Political Economy of Pension Reform in Central-Eastern Europe, Cheltenham, 1999; Müller, K./Ryll, A./Wagener, H.-J. (eds.): Transformation of Social Security: Pensions in Central-Eastern Europe, Heidelberg, 1999; Holzinger, K./Knöpfel, P. (eds.): Environmental Policy in a European Union of Variable Geometry?, Basel, 200o; Ellison, D. L.: CEEC Prospects for Convergence, in: Dauderstädt, M./ Witte, L. (eds.): Cohesive Growth in the Enlarging Euroland, Bonn, 2001, 25-51.

25 Ragnitz, J.: Lagging Productivity in the East German Economy, in: Dauderstädt, M./Witte, L. (eds.), op. cit., 94-105. 
the accession states to stick to the letter of the agreements they had to sign. In that case, rules designed for rich and highly competitive Western economies with stable democracies would be enforced in economically backward and politically fragile Central and Eastern European countries with outcomes that could be as destabilizing as those in some developing countries that were forced by the IMF and the World Bank to cut budget deficits and welfare spending at the height of an economic crisis in order to qualify for international loans. In contrast to East Germany, moreover, where the political repercussions of imposed "Westernization" were buffered not only by transfer payments from West Germany, but also by the integration of elites into the strong political institutions of the Federal Republic, the attempt to rigidly enforce the European acquis in Central and Eastern Europe could delegitimate not only European integration but the democratic regimes of new member states as well.

If these equally unpromising scenarios are to be avoided, the Union needs to find legitimate ways to differentiate the rules that are in fact applied in member states whose economic, social and institutional circumstances would render the uniform application of uniform European rules either impossible or fraught with unacceptable risks. ${ }^{26}$ Under the circumstances, this differentiation cannot be left to the discretion of the Commission and to ECJ judgments in the individual case, where the absence of general standards and the lack of transparency would encourage special pleading and provoke suspicions of favoritism and corruption. At the same time, however, the formulation of general but differentiated standards in the legislative process could turn out to be extremely difficult - and might be counterproductive in policy areas where the salient differences among countries cannot be validly represented by quantifiable indicators, and where it would not be enough to respond to such differences by adopting legislation with quantitatively differing requirements for member states in different categories. At bottom, however, these difficulties differ only in degree from the problems that the EU must also face among its present member states when the seriousness of the challenges discussed immediately below is fully appreciated.

\section{Safeguarding European Welfare States}

European integration has succeeded beyond expectations in widening and deepening the Internal Market and in creating the Monetary Union. But as these economic goals are being realized, the capacity of national governments to

26 Philippart, E./Sie Dhian Ho, M.: Pedalling against the Wind. Strategies to Strengthen the EU's Capacity to Act in the Context of Enlargement, The Hague, 2001. 
influence the course of their national economies and to shape their social orders has also been greatly reduced. Thus Monetary Union has not only deprived member states of the ability to respond to economic problems with a devaluation of the currency, but it has also created conditions under which European monetary policy - which necessarily must respond to average conditions in the Euro Zone at large - will no longer fit economic conditions in individual countries, and hence must contribute to the destabilization of national economies with below-average or above-average rates of inflation and economic growth. Yet while the inevitable misfit of ECB monetary policy increases the need for compensatory strategies at the national level, national governments find themselves severely constrained in their choice of fiscal-policy by the conditions of the Stability and Growth Pact - which will punish countries suffering from slow growth, but can do nothing to discipline the fiscal policies of countries with overheating and highly inflationary economies. ${ }^{27}$ There is little that attempts at macroeconomic co-ordination could do to alleviate this problem. ${ }^{28}$

Moreover, European liberalization and deregulation policies have eliminated the possibility of using public-sector industries as an employment buffer; they no longer allow public utilities and the regulation of financial services to be used as tools of regional and sectoral industrial policy; and European competition policy has largely disabled the use of state aids and public procurement for such purposes. At the same time, European integration has removed all legal barriers to the free mobility of goods, services, capital and workers. Firms may re-incorporate in locations with the most attractive tax regime without affecting their operations, and the Treaties impose very narrow limits on the ability of member states to discriminate in favor of local producers or of their own citizens and taxpayers.

In short, compared to their repertoire of policy choices two or three decades ago, national governments have lost most of their former capacity to influence growth and employment in their economies - most, that is, except for the supplyside options of further deregulation, privatization and tax cuts which are perfectly acceptable under EU law. At the same time, governments face strong economic incentives to resort to just these supply-side strategies in order to attract or retain mobile firms and investments that are threatening to seek locations with lower production costs and higher post-tax incomes from capital. By the same token, workers find themselves compelled to accept lower wages or

27 Enderlein, H.: Wirtschaftspolitik in der Währungsunion, Dissertation Ms. Cologne, Max-Planck Institute for the Study of Societies, 2001.

28 Issing, O.: On Macroeconomic Policy Co-ordination in EMU, in: Journal of Common Market Studies 40/2 (2002), 345-358. 
less attractive employment conditions in order to save existing jobs. Conversely, generous welfare states are also tempted to reduce the availability of tax-financed social transfers and social services in order to avoid the immigration of potential welfare clients.

Taken together, these pressures and temptations are in conflict with the political aspirations and commitments of countries which, in the postwar decades, had adopted a wide range of market-correcting and redistributive policies, creating "social market economies" in which the effects of the capitalist mode of production were moderated through regulations of production and employment conditions, and in which the unequal distribution effects of capitalist economies were modified through public transfers and services financed through progressive taxation. As long as economic boundaries were under national control, such policies could be entirely compatible with vigorous economic development since capital owners could only choose among national investment opportunities, whereas firms were generally able to shift the costs of regulation and taxation onto captive national consumers. ${ }^{29}$ In the absence of tight economic constraints, therefore, politics mattered and governments and unions were within wide limits free to opt for large or small welfare states and for tightly regulated or flexible labor markets. With the removal of economic boundaries, however, these political choices have become comparative advantages or disadvantages ${ }^{30}$ in the Europewide competition for investments, production, and employment.

If these pressures and temptations are not yet fully manifest in the policies of European welfare states, that is largely due to political resistance against the adjustments that would be required by economic concerns in the face of international competitive pressures. But political resistance must often be paid for in terms of lower rates of economic growth and lower rates of employment. ${ }^{31}$ It is no surprise, therefore, that countries and interest groups that have come to rely on extensive regulations of the economy and generous welfare state transfers and services are now turning to the European Union to demand the protection, or creation, of a "European Social Model" that would assume the functions that nation states can no longer perform in the way they had done before the completion of the Internal Market and the Monetary Union.

31

\footnotetext{
Varieties of Capitalism, Oxford, 2001), which denies that competitive pressures must imply institutional convergence, not all existing institutions will convey comparative advantages. Hence the loss of boundary control should still induce countries to "reform" institutions constituting a competitive disadvantage.

Scharpf, F. W.: Governing in Europe, op. cit., chapter 1.

Even under the assumptions of the "varieties-of-capitalism" approach (Hall, P. A./Soskice, D. (eds.): Scharpf, F. W./Schmidt, V.A. (eds.): Welfare and Work in the Open Economy, Oxford, 2000.
} 
In the abstract, these are highly plausible demands. Before European economic integration had its way, both market-making and market-correcting policies had their place at the national level, where competition law had no higher constitutional status than the legislation governing postal services or subsidies to stagnant regions or sectors. If the respective policies were seen to be in conflict, their relative importance had to be determined by political processes, rather than by the constitutional precedence of market making over market correcting concerns. ${ }^{32}$ At the European level, moreover, the much maligned Common Agricultural Policy has demonstrated that it is possible to achieve a similar symmetry of free-trade and social-protection policies. Moreover, the successful harmonization of health and safety regulations of foodstuffs, consumer goods and machinery has shown that European institutions are also capable of re-regulating liberalized product markets. ${ }^{33}$ So why not also combine the policies creating and liberalizing European markets for goods, services and capital with the European harmonization of market-correcting social regulations and taxes?

Economically, that would indeed be feasible. While there is presently much public commotion about the destabilizing consequences of "globalization", the fact is that the world economy is much less integrated, and hence much less constraining, than is the Internal Market. At the same time, the European Union is much less dependent on imports and exports than its member states, and with the creation of the Monetary Union it has become much less vulnerable to the vicissitudes of international capital markets. In abstract economic theory, therefore, macroeconomic management, industrial policy and the social regulation and taxation of business activities, which have become constrained at the national level, would still be economically feasible policy options for the European Union. This, in fact, had been the promise of the "Social Dimension" which Jacques Delors had associated with the Internal-Market initiative and, again, with the creation of the Monetary Union. Unfortunately, however, this promise was not, and could not be fulfilled within the present institutional framework of the European polity.

\section{The European Dilemma: Consensus and Uniformity}

But why is it that the new challenges discussed here cannot be met effectively within the present institutional and policy framework of the European Union? The short answer is that effective solutions could not, at the same time, be

32 Scharpf, F. W.: Governing in Europe, op. cit., chapter 1.

33 Eichener, V., op. cit. 
uniform and consensual - and that both of these requirements are closely associated with the legitimacy of European policy making.

The notion that European integration ought to take the form of uniform rules applying equally throughout all member states has a high normative salience in Europhile discourses. It is associated with idealistic aspirations for a European collective identity and commitments to common citizenship and solidarity. At the same time, however, hard-nosed market liberalizers, if they cannot get deregulation and mutual recognition, will also insist on uniform product standards to eliminate non-tariff barriers, uniform process regulations to create a "level playing field", and uniform competition rules to prevent discrimination. And even where, in the absence of compelling economic pressures, differences among national legal systems are pragmatically tolerated for the time being, that tolerance does not extend to European law itself - whose very raison d'être is not only to overcome and remove national obstacles to free trade, but also to create a unified European legal order.

In practice, diversity is of course often accommodated by "stealth" and "subterfuge" in European policy processes ${ }^{34}$, and there have also been explicit compromises. Accession countries had to be granted periods of grace before the uniform acquis would fully apply in all policy areas; not all member states have yet become part of the Monetary Union or of the "Schengen Area"; and political opt-outs had to be accepted in foreign policy and social policy as well. But these are considered exceptions that cannot invalidate the principle that European policy, whether adopted in the supranational-hierarchical mode, in the joint-decision mode or in the intergovernmental mode, should be uniform throughout the territory of the Union's member states.

In a formal sense, the requirement of consensus-based policy making follows from present decision rules. It applies explicitly to decisions that have to be reached in the intergovernmental mode, and in practice broad consensus is also achieved in the joint-decision mode, even where the Council may decide by qualified majority. By contrast, consensus among member governments is not required in the supranational-centralized mode. But as I have pointed out above, the delegation of supranational powers is generally premised on a pre-existing intergovernmental agreement on the purposes that are to be achieved and on the rules under which they are to be exercised.

The twin requirements of consensus cum uniformity worked well for the basic commitment to economic integration, and they also worked, under the political and economic conditions of the mid-1980s, for the commitment to liberalization 
and for the harmonization of product standards which, at least in principle, had the support of consumers and producers in all member states. By comparison, consensus on uniform environmental regulations of production processes was more difficult to achieve. ${ }^{35}$ In none of these areas, however, was the combination of uniformity and consensus as problematic as it is with regard to the new challenges discussed above.

In the field of European security policy, common and uniform policies would indeed be highly desirable from a problem-solving perspective. If the combined political and military potential of its member states were available for common strategies, the EU would be fully capable of dealing with its own security concerns and those in its neighborhood without having to wait for American leadership. ${ }^{36}$ The problem is consensus. For the reasons discussed above, it is most unlikely that agreement on common solutions ensuring effective and speedy diplomatic and military action could be reached in a field so closely associated with core ideas of national sovereignty and with issues of war and peace whose salience in national politics is shaped by divergent historical legacies and normative orientations.

For Eastern enlargement, by contrast, the problem is uniformity. Given the wide economic gap between even the most advanced candidate states and the least well-off among present member states, and the enormous differences in the social, political and institutional starting positions of the candidates, uniform European rules imposed on all accession states appear undesirable from a problem-solving perspective. What would be desirable are policies and accession requirements reflecting existing differences and allowing each country to find its own path toward economic viability and political legitimacy within the framework of EU institutions and of a subset of EU standards defining a "core acquis". ${ }^{77}$ In fact, however, uniformity is likely to be imposed. The Commission is in charge of accession negotiations and it is conducting them bilaterally with each candidate government - which implies a supranational-centralized mode similar to the one in which the Commission is enforcing EU law against individual member states. Since the Commission's judgment of a candidate's "readiness" for accession is premised on acceptance of the full acquis, present member governments and the Council are not even presented with the option of agreeing to a subset of "core" standards or to differentiated requirements for individual candidate coun-

35 Scharpf, F. W.: Governing in Europe, op. cit.; Eichener, V., op. cit.

36 Freedman, L.: Rethinking European Security, in: Wallace, H. (ed.): Interlocking Dimensions of European Integration, Basingstoke, 2001, 215-230.

37 Philippart, E./Sie Dhian Ho, M., op. cit. 
tries. The danger is, therefore, that uniform standards will be imposed without regard to the severity of the problems which they will entail.

In the fields of tax and social policy, finally, uniformity might be desirable from a problem-solving perspective, but it could not be obtained under institutional conditions requiring high levels of consensus because member states will disagree on the choice of a common solution. One reason is that some countries may have no interest in common solutions. Unregulated tax competition, for instance, may actually benefit small countries whose revenue from capital inflows may outweigh revenue losses from tax cuts - which larger countries could not reciprocate. ${ }^{38}$ Similar conflicts follow from differences in economic development. Thus, the provision of social transfers and of public social services at the level that is considered appropriate in the Scandinavian countries could simply not be afforded by less rich member states like Greece, Spain or Portugal, let alone in the candidate countries on the threshold of Eastern enlargement. Of even greater importance, however, is the fact that European welfare states have come to define widely differing dividing lines between the functions the state is expected to perform and those that are left to private provision, either in the family or by the market. ${ }^{39}$ Differences of similar significance are also characteristic of the industrial-relations institutions of EU member states. ${ }^{40}$

These structural differences are not merely of a technical nature but have high political salience. They correspond to fundamentally differing welfare-state aspirations which can be roughly equated with the historical dominance of "liberal", "christian democratic" and "social democratic" political parties and social philosophies. ${ }^{41}$ Moreover, and perhaps more important: Citizens in all countries have come to base their life plans on the continuation of existing systems of social protection and taxation, and any attempts to replace these with qualitatively different European solutions would mobilize fierce opposition. Voters in Britain simply could not accept the high levels of taxation that sustain the generous Swedish welfare state; Swedish families could not live with the low level of social and educational services provided in Germany; and German doctors and patients would unite in protest against any moves toward a British-style National Health System. There is, in short, no single "European social model" on which harmonization could converge. ${ }^{42}$ National governments, accountable to their national

38 Dehejia, V.H./Genschel, Ph.: Tax Competition in the European Union, in: Politics and Society $27 / 3$ (1999), 403-430.

39 Scharpf, F. W./Schmidt, V.A. (eds.), op. cit.

40 Crouch, C.: Industrial Relations and European State Traditions, Oxford, 1993; Ebbinghaus, B./Visser, J.:

Trade Unions in Western Europe Since 1945, London, 2000.

41 Esping-Andersen, G.: The Three Worlds of Welfare Capitalism. Princeton, 1990.

42 Ferrera, M./Hemerijck, A. C./Rhodes, M.: The Future of Social Europe, Oeiras, 2000. 
constituencies, thus could not possibly agree on common European solutions for the core functions of the welfare state. ${ }^{43}$

\section{Two Non-Solutions: Subsidiarity and Majority Rule}

If uniformity cum consensus cannot be attained at the European level, two conventional solutions, subsidiarity or majority rule, are most likely to be proposed. The first one would avoid the Europeanization of policy choices and leave member states to cope with the problems; the second one would call for institutional reforms allowing uniform policies to be imposed by majority vote in the Council. For the problems discussed here, however, neither of these solutions is likely to be appropriate.

"Subsidiarity" as defined in Art. 5 II TEC allows the Europeanization of policy only if "the objectives of the proposed action cannot be sufficiently achieved by the Member States", and if it is also true that these objectives can "be better achieved by the Community". The principle provides no guidance, however, if the first condition should be true and the second one false - which is precisely the situation encountered by the new challenges discussed here. On the basis of what was said above, common (and uniform) European solutions would be either undesirable or politically unfeasible under present voting rules in all three instances. But that would not imply a superiority of national alternatives.

As for a Common Foreign and Security Policy, there is no question that its objectives could not be achieved by autonomous national action. Similarly, if there is a need for adjusting the acquis in the process of Eastern enlargement, the Union could not simply leave the definition of such rules to individual accession states. It is thus only with regard to challenges affecting European welfare states that subsidiarity might be considered a serious option. For libertarian authors, it would ensure the constitutional superiority of economic liberties guaranteed by the Treaties over all market-restraining policies adopted at national level. ${ }^{44}$ By a different line of normative reasoning, Giandomenico Majone would also assign welfare-state policies to national levels where redistributive policy choices could be legitimated by democratic procedures that are as yet unavailable in the European polity. ${ }^{45}$

43 Scharpf, F.W.: The European Social Model, in: Journal of Common Market Studies 40/4 (2002), 645669.

44 Mestmäcker, E.-J.: Zur Wirtschaftsverfassung in der Europäischen Union, in: Hasse, R. H./Molsberger, J./ Watrin, C. (eds.): Ordnung in Freiheit, Stuttgart, 1994, 263-292.

45 Majone, G.: Regulating Europe, London, 1994. 
However, neither of these positions takes account of the legal and economic constraints that European integration has imposed on national policy choices in the fields of taxation, social protection and industrial relations. It is true that theoretical and empirical research on the viability of welfare states under conditions of globalization has, by and large, noted significant differences (and a good deal of path-dependent resistance) in the responses of national welfare state regimes to the downward pressures of economic competition. ${ }^{46}$ It should also be noted, however, that successful countries often had the benefit of favorable economic or institutional legacies, and that more countries are either stuck in economic difficulties or had to accept a considerable increase in social inequality and insecurity. In any case, purely national solutions will always be constrained by the "supremacy" and "direct effect" of European rules assuring market integration, free movement, and undistorted competition. ${ }^{47}$

From a problem-solving perspective, therefore, the new challenges discussed here seem to require European solutions. If these are nevertheless blocked by lack of agreement among member states, it may then appear plausible to move from consensual policy making to majority rule - which would allow uniform European policies to be adopted even in the face of intergovernmental conflict. While that would not be directly useful for the problems of Eastern enlargement, it would certainly make a difference for the feasibility of a Common Foreign and Security Policy, a common European tax policy, and a European social policy just as the introduction of qualified-majority voting in the Single European Act had ensured the success of the Internal-Market program. The same idea is implied in Joschka Fischer's vision of the EU as a democratic federation ${ }^{48}$ in which, presumably, simple majorities in both chambers of the legislature would suffice for European policy choices - and proposals to extend majority voting also seem to be high on the agenda of the present Convention.

Garrett, G.: Partisan Politics in the Global Economy, Cambridge, 1998; Swank, D.: Funding the Welfare State, in: Political Studies 46/4 (1998), 671-692; Scharpf, F. W./Schmidt, V.A. (eds.), op. cit.; Pierson, P. (ed.): The New Politics of the Welfare State, Oxford, 2001; Huber, E./Stephens, J.D.: Development and Crisis of the Welfare State, Chicago, 2001.

47 Scharpf, F. W.: Governing in Europe, op. cit. Such constraints would also apply to the service public and infrastructure functions and the industrial-policy options of national and subnational governments which the French and German governments have been trying to protect (Héritier, A., op. cit.; LyonCaen, A./Champeil-Desplats, V. (eds.): Services Publics et Droits Fondamentaux dans la Construction Européenne, Paris, 2001; Franßen-de la Cerda, B./Hammer, G.: Das „Berliner Modell“ zur Kompetenzabgrenzung zwischen der Europäischen Union und ihren Mitgliedstaaten, in: Zeitschrift für Politikwissenschaft 11 (2001), 1011-1044).

48 Fischer, J.: From Confederacy to Federation, in: Joerges, Ch./Mény, Y./Weiler, J.H. H. (eds.): What Kind of Constitution for What Kind of Polity?, Florence, 2000, 19-30 (http://www.iue.it/RSC/symposium/). 
But quite apart from the question of whether governments would agree to the abolition of veto powers in the next Intergovernmental Conference, such proposals could undermine the legitimacy of EU policy processes. Voting by qualified majority has become a pragmatically useful device for speeding up Council decisions in constellations where the divergence of policy preferences does not have high political salience in national constituencies - or where divergent preferences are delegitimated by reference to clearly understood commitments to an overriding common purpose. But if neither of these conditions is fulfilled, the use of majority votes to override politically salient national preferences could blow the Union apart. The EU is not (yet) itself a unified polity with generalpurpose democratic legitimacy, and its voters do not (yet) constitute an integrated constituency with Europe-wide public debates, Europe-wide party competition, and effective political accountability. ${ }^{49}$ Where divergent national preferences are not delegitimated by agreed-upon common goals, therefore, politically salient EU policies must still depend on the willingness of democratically accountable member governments to assume political responsibility. ${ }^{50}$ In the face of legitimate diversity, therefore, intergovernmental disagreement cannot be overcome by majority rule. Instead, there is a need for governing modes that are able to accommodate diversity while dealing effectively with the problems that can only be resolved at the European level..$^{51}$

\section{European Action in the Face of Legitimate Diversity}

If the legitimate diversity of national preferences has sufficiently high political salience at national levels to prevent agreement on uniform European policies, and if strictly national policies cannot provide effective responses to urgent problems, there is a need for differentiated European policies that are able to

49 Scharpf, F. W.: Governing in Europe, op. cit.

50 Lepsius, M.R.: The European Union as a Sovereignty Association of a Special Nature, in: Joerges, Ch./Mény, Y./Weiler, J.H. H. (eds.), op. cit., 213-222; Weiler, J. H. H.: Fischer: The Dark Side, in: Joerges, Ch./Mény, Y./Weiler, J.H.H. (eds.), op. cit, 235-247.

51 Under certain conditions, European action might also be facilitated by devising solutions that have less political salience at national levels. In the context of ESDP, for instance, one might imagine a European Rapid Reaction Force that is not composed of national contingents, but created as an organizationally separate European volunteer army and financed entirely from the EU budget. If this genuinely European capacity for military action were in existence, national governments would still have to take political responsibility for specific mandates. But one should expect that agreement on these would have to overcome fewer national reservations, and that the implementation of such mandates could to a larger extent be delegated to a supranational command structure. 
accommodate divergent national problems and preferences. In the present institutional structure of the EU, there are two options, "Closer Cooperation" and the "Open Method of Coordination" which could possibly be employed for this purpose.

The provisions on "Enhanced Cooperation" in Title VII of the Treaty of European Union are meant to allow groups of member governments to make use of EC institutions to adopt and implement European policies that will apply only to the participating members states (Art. 44 TEU). In theory, these options might be usefully employed in the field of foreign and security policy and with regard to the challenges of Eastern enlargement. Their potentially most useful application, however, could be in policy areas where national problem-solving capacities are undermined by economic integration.

Thus, high-tax countries might harmonize profit taxes at least among themselves; highly industrialized countries could jointly adopt more stringent environmental regulations than would be acceptable for less developed member states; and Southern and Eastern member states could agree on common standards for systems of means-tested basic income support. By the same token, countries financing health care through compulsory health insurance could harmonize their regulations for the licensing and remuneration of service providers; countries considering the partial privatization of public pension systems could harmonize their regulations of investment options; countries wishing to maintain efficient and affordable local transport could jointly regulate the competition among public and private providers; and the same could be done by countries committed to the maintenance of public-service television.

What matters is that the rules so adopted would have the force of European law in the vertical as well as the horizontal dimension. Vertically, they would be binding on national and subnational policy makers - which implies that the temptations of tax and regulatory competition would be eliminated among members of the group. Even more important in many cases would be the horizontal effect: The regulations so adopted would have the same legal status as other provisions of European law - which implies that conflicts between marketliberalizing and social-protection goals would have to be resolved by a "balancing test" at the European level, rather than being automatically settled by the "supremacy" of European liberalizing rules over national social-protection rules. ${ }^{52}$

So why were the statements in the preceding paragraph all phrased in the conditional mode? The proximate reason are conditions defined in the Treaty of 
Amsterdam that are so restrictive that there are no present examples of closer cooperation. ${ }^{53}$ Thus, enhanced cooperation was allowed only for groups whose membership includes "at least a majority of Member States" (Art. 43 I d TEU). Moreover, permission had to be granted by the Council "acting by qualified majority on a proposal of the Commission" (Art. 11 II para 1 TEC), and that decision could be prevented by the opposition of single member state invoking "important and stated reasons of national policy" (Art. 11 II para 2 TEC). These extremely restrictive conditions were marginally liberalized by the Treaty of Nice, but the requirement that a minimum of eight member states must participate would still exclude most of the potential examples suggested above. In addition, the Treaty of Amsterdam ruled out agreements that would "affect the 'acquis communautaire' and the measures adopted under the other provisions of the (...) Treaties" (Art. 43 I e TEU) or that would "constitute a discrimination or a restriction of trade between Member States and (...) distort the conditions of competition between the latter" (Art. 11 I e TEC).

This apparent hostility against closer cooperation is in part explained by the fierce defense of the acquis by the Commission - and the dominance of economic integration and liberalization discourses within the Commission. But why should governments - which could overrule the Commission in the process of Treaty reform - share that aversion? The answer, I suggest, is a case of unfortunate "framing". Regardless of the variety of terms that have been used since the early $1970 s$ - "variable speed", "variable geometry", "concentric circles", "two tiers", "core" or most recently, "pioneer group" - the notion of differentiated integration has typically been associated with the image of greater or lesser progress along a single dimension from less to more integration. ${ }^{54}$ The idea was that an "avantgarde" of member states that were able and willing to move ahead should be allowed to do so - which immediately suggested that all others would find themselves in the rear guard and might be relegated to second-class citizenship in Europe. This framing of the discussion is unfortunate, but it seems too deeply entrenched to be overcome in the near future.

53 It would be more correct to say that examples which do in fact exist did not come about under the rules governing "Closer Cooperation". Monetary Union has become the most important one of these examples, but the "Schengen Area", even after it was brought under the Treaty, also does not include all EU member states, and the same is true of CESDP.

54 See Ehlermann, C.-D.: How Flexible Is Community Law? An Unusual Approach to the Concept of "Two Speeds”, in: Michigan Law Review 82 (1984), 1274-1293; Giering, C.: Vielfalt in Einheit - die Flexibilisierung der europäischen Integration, in: Europa Institut Zürich (ed.): Die Europäische Union, Zürich, 191-210; Walker, N.: Sovereignity and Differentiated Integration in the European Union, in: European Law Journal 4/4 (1998), 355-388; Búrca, G. de/Scott, J. (eds.): Constitutional Change in the EU, Oxford, 2000. 
The same objections do not apply to the second option, the "Open Method of Coordination" which - avant la lettre - was established in the Maastricht Treaty for the coordination of economic policies of member states (Arts. 98 and 99 TEC) and applied to employment policies in the Amsterdam Treaty (Arts. 125-130 TEC). Without amending the Treaty, the Lisbon Summit then introduced the generic label and proceeded to apply it to a few industrial and social-policy goals. The method implies that member governments should agree to define certain policy purposes or problems as matters of "common concern", whereas the actual choice of effective policies should remain a national responsibility. Its core is an iterative procedure, beginning with a report from the Commission to the European Council which is followed by guidelines of the Council based on a proposal from the Commission. In response to these guidelines, member governments will present annual "national action plans" and reports on measures taken - which will then be evaluated in the light of comparative "benchmarks" by the Commission and a permanent committee of senior civil servants. These evaluations will feed into the next iteration of annual reports and guidelines, but they may also lead to the adoption of specific recommendations of the Council addressed to individual member states. However, "the harmonization of the laws and regulations of Member States" is explicitly excluded from the measures the Council could adopt (Art. 129 TEC).

It is too early for a definitive evaluation of the problem-solving effectiveness of the open method of coordination ${ }^{55}$, but its potential and its limitations seem to be quite clear. Since member states remain in control of their own policy choices, they also remain capable of responding to the diversity of national economic and institutional conditions and of national preferences. Nevertheless, by exposing their actual performance to comparative benchmarking, peer review and public scrutiny, open coordination could provide favorable conditions for "learning by monitoring" ${ }^{56}$, and it may also contribute to shaming governments out of "beggar-my-neighbor" strategies that would be self-defeating if everybody did adopt them. At the same time, however, it is also clear that the policies so adopted will have the status of national law and thus will remain vulnerable to all the legal constraints imposed by the "supremacy" of European rules of market integration,

55 But see Goetschy, J.: The European Employment Strategy, in: European Journal of Industrial Relations 5/2 (1999), 117-137; Hodson, D./Maher, I.: The Open Method as a New Mode of Governance, in: Journal of Common Market Studies 39/4 (2001), 719-747; De la Porte, C./Pochet, Ph. (eds.): Building Social Europe Through the Open Method of Coordination, Bruxelles, 2002.

56 Sabel, Ch.F.: Learning by Monitoring, in: Smelser, N./Swedberg, R. (eds.), Handbook of Economic Sociology, Princeton, 1995, 137-165; Visser, J./Hemerijck, A. C.: Learning Ahead of Failure, Ms. University of Amsterdam, 2001. 
liberalization and competition law. As a consequence, they will do little to alleviate the impact of the acquis on accession states or to protect European welfare states against the pressures of regulatory and tax competition. ${ }^{57}$

In its "White Paper on European Governance" 58, the Commission itself appears to be quite unenthusiastic about the open method of coordination and it also insists that it "should not be used when legislative action under the Community method is possible". ${ }^{99}$ Instead, it suggests that Council and Parliament should more often adopt "framework directives" that leave more room for the discretion of national policy makers. ${ }^{60}$ If that suggestion is rarely acted upon, one reason could be mutual distrust among member governments who might doubt each other's good faith in carrying out burdensome legislative mandates or in resisting the temptations of protectionist beggar-my-neighbor practices.

But these suspicions could be alleviated if framework directives were coupled with the open method of coordination. Then member states would have to describe their chosen methods of implementation and report on their effects, while their performance would be monitored and compared by the Commission and evaluated by peer review and by the Council. If evaluation should reveal general problems, the framework legislation could be amended and tightened. With regard to specific implementation deficits in individual countries, moreover, the Council could not merely issue recommendations but adopt legally binding decisions or authorize ${ }^{61}$ the Commission to initiate the usual infringement proceedings. In other words: Member states would retain considerable discretion in shaping the substantive and procedural content of framework directives to suit specific local conditions and preferences. Yet if they should abuse this discretion in the political judgment of their peers in the Council, more centralized sanctions and enforcement procedures would still be available as a "fleet in being".

At the same time, the effectiveness of open coordination would be increased if its procedures were embedded in the context of framework directives which, like all other directives, have the quality of European law. Thus, in the vertical dimension, their implementation is not left to the discretion of national governments, and actors in charge of national policy choices in the respective sectors could not

57 Scharpf, F. W.: The European Social Model, op. cit.

$58 \mathrm{COM} 2001 / 428$.

59 Ibid., 22.

60 Ibid., 20.

61 The flexibility of Open Coordination might be lost if the Commission could automatically resort to infringement proceedings whenever it saw the uniformity of European law threatened by differentiated national solutions. Thus it would seem desirable to require the special authorization by a majority in the Council. 
simply ignore agreements at the European level. By the same token, the existence of a legal obligation could help to overcome domestic opposition against the policy choices required by good-faith implementation. In the horizontal dimension, moreover, the policies so adopted would have the status of European law and hence would not be asymmetrically constrained by market-making policies adopted at the same European level.

Differentiation could be taken one step further if framework directives and open coordination were applied to achieve the purposes of enhanced cooperation discussed above. Technically, that would be easy to achieve since a directive, unlike regulations, is only "binding upon each member state to which it is addressed" (Art. 249 para 3 TEC). It would thus be possible to adopt framework directives dealing specifically with the common problems of a group of member states. In contrast to the rules for enhanced cooperation, participation in the decision-making process could not be formally restricted to members of the group - which would increase transaction costs but might also help to avoid the distrust against attempts at differentiated integration.

\section{Conclusions}

Present debates on the European constitution would benefit from a focus on the substantive policy problems that cannot be effectively resolved through the existing governing modes of the European Union. While these modes differ from one another, they share two essential requirements: effective European policy depends on high levels of consensus among member governments, and it must, at least in principle, provide for uniform rules across all member states. By and large, these requirements could be simultaneously satisfied in the policy processes that brought about economic integration. That is no longer true of a set of new challenges that the Union must now deal with - among which I have discussed the need for rapid peace-keeping and peace-making interventions in conflicts

affecting common European security, the need to facilitate the economic, social and political development of accession states in Central and Eastern Europe, and the need for protecting the plurality of "European social models" against the constraints and pressures of integrated markets. In each of these areas, the dual conditions of broad consensus and uniform policy cannot be satisfied at the same time.

In dealing with these challenges, the Union is confronted with a dilemma: Purely national solutions will not be effective, but common and uniform European solutions could not be adopted in consensus in the face of a "legitimate 
diversity" of national preferences. Under these conditions, neither resort to the principle of "subsidiarity" nor a move toward majoritarian decision rules could provide effective and legitimate solutions. The Union is not now, and will not soon be a unified democratic polity, and it would undermine the bases of its own legitimacy if highly salient political preferences of its member states could simply be overruled by majority votes in the Council and the European Parliament.

If the present constitutional debate is to be useful, therefore, it ought to be about new modes of European governing that will allow effectively Europeanized responses to the new challenges facing the Union which are also able to accommodate legitimate national diversity. Two such options, "Enhanced Cooperation" and the "Open Method of Coordination", already have a base in the present Treaties. However, the first of these is crippled by overly restrictive conditions which were not significantly relaxed in the Nice Treaty, whereas the second option may facilitate policy learning at national levels but cannot achieve the legal effectiveness of European policy solutions. It might be promising, therefore, to consider Open Coordination in combination with European "framework directives" that are legally binding but leave the specification of more detailed substantive and procedural rules to national governments. 